\title{
Nietzsche ainda cresce ${ }^{*}$
}

\author{
Cleto Seabra Veloso**
}

Resumo: Texto publicado jornal carioca Diário de Notícias, em 1945. Nele, o autor procura afastar a obra de Nietzsche das leituras que teimam em associá-la com o nazismo.

Palavras-chaves: Nietzsche - obra - nazismo

Nietzsche foi o que se pode chamar um espírito extraordinariamente privilegiado. É o que sugere a leitura dos seus trabalhos, da sua obra.

Ah, a sua obra! A que região profunda e estranha, derramada entre montanhas alvíssimas, povoada de árvores diferentes, florestas diferentes, água luz e ar diferentes, - ela conduz, em horas de séria meditação!

"Quando se entra em contato com os livros de Nietzsche, diz Stefan Zweing, se aspira o ozônio, um ar puro, elementar, desprovido de pressão, de nebulosidade ou de densidade; ver-se livremente nesta paisagem até o mais alto firmamento, e respira-se um ar único, um ar feito para corações robustos e espíritos livres".

Não tenho a menor ideia na minha vida de adorador das grandes inteligências, de haver deparado figura mais singular do que a de Nietzsche.

Qualquer mortal, seja ele um sábio, um poeta ou um santo, quando levado pelas suas convicções, pelos seus ideais, pela sua aspiração, pelo seu amor, a produzir algo próprio, - é evidente que

* Publicado no Diário de Notícias. Rio de Janeiro, 21 Outubro de 1945, p. 01-05.

** Cleto Seabra Veloso. Médico, escritor. 
tropeça com as maiores dificuldades ao pretender arrumar o produto de sua imaginação, flor ou fel que seja, - no exíguo e mal arranjado leito de Procusto, que são os idiomas em que o vazamos, mesmo sendo estes os mais flexíveis, elásticos e ricos em imagens coloridas. Todos sabem o que seja vestir uma ideia verdadeiramente grandiosa com essa roupagem de palavras esfarrapadas, desiguais, vulgares e cediças por muito repetidas, desde que o mundo é mundo. Para Nietzsche, ao que parece, não havia tais dificuldades. Copiando um esgrimista dos mais hábeis e ferozes, ele maneja tão bem o sabre como a espada, o florete como o punhal, a pena como o verbo. E com esse opulento material próprio, deu-se ao prazer e ao sacrifício de descobrir e proclamar as mais arrasadoras verdades, jamais pronunciadas. Foi assim que o grande cristianismo, com todos os seus defeitos teológicos, se transforou em suas mãos ciclópicas em fragmentos de comovedora fragilidade. Foi assim que grandes artistas (grandes no sentido lato do vocábulo), foram malbaratados e reduzidos a frangalhos. Foi assim que filósofos, sábios e literatos se transformaram em figuras caricatas, medíocres e vulgares.

Comparo a energia mental de Nietzsche, no gênero humano, à força física do pequeno escaravelho, no gênero dos insetos. Como este Nietzsche dispunha de força suficiente para carregar uma centena de vezes o peso de seu corpo, o peso de sua infindável tragédia. Zumbiu e esbravejou a vida toda, por todos os recantos da imaginação, da nobre compreensão, do mundo-verdade, da vida perigosa, sem máscaras ou quaisquer outros artifícios. Sempre detestou o repouso intelectual, a entropia, tão ao agrado da maioria dos homens chamados diferentes. "É pernicioso ao pensador, dizia Nietzsche, estar sujeito a uma só pessoa. Quando alguém conseguir encontrar a si próprio, é preciso que se perca de novo, para depois voltar a encontrar-se".

Deveras o que acho diferente em Nietzsche não são as chamadas ideias geniais: "Super-homem", "Eterno Retorno", "Vontade do Poder", porque nelas topo muito fogo de palavras para pouco 
sentido honesto das coisas e da vida. De resto, quem poderá dizer até se a humanidade em lugar do evoluir para o "Super-homem", como o "sentido do mundo", distorce-se e regride para o "Sub-homem", hipersensível, histórico e com um físico degenerado? ! Se assim acontecer, será o "Sub-homem" algum dia o "sentido do mundo", numa "inversão total dos valores". Porém isso não importa. Não vem ao caso. $\mathrm{O}$ que realmente surpreende em Nietzsche é essa faculdade chamada inteligência. Capaz, nele, de tirar da verdade ou do erro, do bem ou do mal, da opulência ou da significância, os mais prodigiosos efeitos. A mísera terra se transforma em suas mãos mágicas nos mais raros e diferentes materiais. Quando ele entende fabricar ouro, platina ou oxigênio faz com a mesma segurança e agilidade com que despeja um vidro de vitriolo sobre um leito. Não há, a bem dizer, limites para a sua compreensão da intuição no terreno das coisas possíveis. Que desgraça, por exemplo, para George Sand, quando atira, mesmo de longe, o veneno. Como lhe cai bem, entre outras tantas brasas, o qualificativo fêmea. Do mesmo modo, está nas alturas, quando diz que a música de Wagner sua, quando aguilhoa Hugo ou Balzac, ou quando ironiza Kant.

Em verdade o primeiro sentimento elevado que a obra desperta, a quem dela se aproxima, é um imediato respeito pelo poder da inteligência. Inteligência grande e soberana. Capaz de toldar de sangue um oceano ou de abrir uma brecha no firmamento, muito embora saibamos, de antemão que é absolutamente impossível quer uma quer outra coisa.

Já me considero velho em matéria de ver, sentir e pensar. Quando, pois, deparo no caminho a que me conduz a alta leitura, com um Gênio, um Filósofo ou um Santo, não me permito mais o direito aos entusiasmos fáceis e, até certo ponto pueris, dos jovens enfeitiçados, daqueles para os quais a vida é uma via láctea de alelos, de vibrações, de sons, de vitória! As rosas, as madressilvas e as primaveras do meu canteiro despertam em mim admiração e beleza, não há dúvida. Mas nem por isso, eu as vejo mais rosas, mais madressilvas ou mais primaveras do que elas realmente são, 
isto é, rosas, madressilvas e primaveras, todas cheias de perfume e sensível beleza. As lentes de aumento da minha inteligência, dos meus sentimentos, do meu entusiasmo aumentam os objetos até um certo limite, comparável com o decoro e equilíbrio, que o trata com a vida, resignado e altivo me impõe. Tudo que exceder a esse marco prefixado pela nossa autocrítica, pela nossa autoignorância, pela nossa autorresponsabilidade, é incerto e duvidoso e não deve merecer a atenção dos verdadeiramente esclarecidos.

Estas considerações vêm a propósito do que acabo de dizer a respeito de Nietzsche. Não quero, ao fazer tais afirmações, ser tomado pelos nossos contemporâneos, como um sonhador, um idealista nessas alturas porque anda o mundo, tardiamente fascinado pelas maravilhas do estilo de Nietzsche, pelo seu delírio, pelas suas afirmações e fantasias, pela sua coragem, pelos seus arrebatamentos. Não! O meu entusiasmo por Nietzsche é muito pensado, dirigido e, só então, assimilado. Não engoli, de modo algum, uma droga cujo conteúdo contenha, por ventura, um explosivo.

Nietzsche ainda precisa ser meditado e estudado. Porém, contudo por gente e não por vermes. Tenho a impressão, cada dia mais arraigada, que é da escavação desses tesouros, já tantas vezes revolvidos e devassados - que há de surgir a nova luz, a nova ordem para grandes e pequenos no mundo de nossos dias.

Porém a interpretação de homens como Nietzsche, repito, não está ao alcance de políticos, reformadores, educadores ou filósofos, no sentido atual que se empresta a estes vocábulos. Tal interpretação pertence, por todos os motivos e razões, justamente àqueles homens mais tribulados e desprezados por ele. Refiro-me aos biógrafos, aos cientistas. Aos homens que naquele tempo faziam e hoje ainda fazem ciência para a humanidade.

Quem dirá se de um estudo desta natureza, do qual tomariam parte um Wells, um Durant, para citar apenas dois nomes, - não brotaria "qualquer coisa" capaz de iluminar as trevas, ou se quiserem, capaz de corrigir o excesso de claridade que obumbra, o "homo sapiens", atolado na barbárie?! 
A obra genial desse homem que se chama Friedrick Nietzsche, sempre revoltado com a justiça de Deus, e com a ignorância do próximo, não tem culpa que um histérico como foi Hitler dela se sirva para satisfação de suas paixões animais. Referindo-se a Nietzsche, ele, como fala Durant: "Como ardia por ser um pecador, esse irredutível santo".

A dialética militarista e guerreira de Nietzsche é obra de pura imaginação. No fundo ele era um piedoso, um bom, mais apolíneo do que dionisíaco, mais Parsifal do que Siegfried, apesar de todos os seus recalques infernais. Por tudo isso Nietzsche ainda cresce na admiração e no respeito do mundo.

Abstract: Text published newspaper Daily News in 1945, in Rio de Janeiro. In it, the author seeks to dispel the work of Nietzsche readings that insist on associating it with Nazism.

Keywords: Nietzsche - work -nazism 
